\title{
Critical Analysis of the Current State of Knowledge in the Field of Waste Heat Recovery in Sewage Systems
}

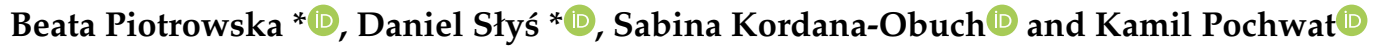 \\ Department of Infrastructure and Water Management, The Faculty of Civil Environmental Engineering and \\ Architecture, Rzeszow University of Technology, Av. Powstancow Warszawy 6, 35-959 Rzeszow, Poland; \\ sk@prz.edu.pl (S.K.-O.); kp@prz.edu.pl (K.P.) \\ * Correspondence: b.piotrowska@prz.edu.pl (B.P.); daniels@prz.edu.pl (D.S.); \\ Tel.: +48-17-865-1071 (B.P.); +48-17-865-1784 (D.S.)
}

Received: 5 May 2020; Accepted: 5 June 2020; Published: 8 June 2020

\begin{abstract}
The need for efficient use of energy and sustainable energy management and the fact that large quantities of heat are deposited in the discharged sewage have contributed to the development of research on waste heat recovery. Gray water began to be seen not just as waste, but also as an alternative source of energy. Research related to the development, improvement, and finally, the popularization of waste energy recovery devices and systems has evolved rapidly over the last two decades. Initially, technologies for gray water reuse were not widely used, which was due to the low efficiency of the current heat exchangers and the significant investment outlays that would have to be covered by potential users. Research conducted by scientists from around the world has allowed us to eliminate construction flaws, improve efficiency, and also provide information on the selection of optimal waste heat recovery technology, depending on the installation conditions and operating parameters. The ability to correctly select the device allows for effective energy collection from gray water, which improves the investment profitability. This paper reviews the research regarding issues related to waste heat recovery from gray water in sewage installations and systems. A critical analysis of the current state of knowledge was carried out with a special consideration to the technologies intended for the residential buildings.
\end{abstract}

Keywords: waste heat recovery; drain water heat recovery; domestic hot water; sewage systems; alternative energy sources

\section{Introduction}

The International Energy Agency (IEA) regularly compiles and publishes reports regarding the global energy policy [1-6]. According to the 2019 report [1], electricity consumption in the residential and commercial building sector is still growing. In countries which are members of the Organization for Economic Co-operation and Development (OECD), this increase is projected at around $0.4 \%$ per year until 2050. It is also estimated that the share of the construction sector in global energy consumption will increase from around 20\% observed in 2018 to $22 \%$ predicted in 2050. According to the data published by the IEA, energy demand for residential buildings in non-OECD countries may increase by up to $70 \%$ compared to the present day level $[1,2]$. The presented forecasts for the increase in energy demand are related primarily to the growing demand for services, economic development, and continuous population growth. IEA predicts, in the 2018 Renewables [4] document regarding the technology and renewable energy, an increase in the share of renewable energy sources in 2023 of $20 \%$. The reports also provide information about a decrease in coal consumption in the building sector, which is most often used for room heating and preparing domestic hot water [4]. 
Experts estimate that by conducting a more effective energy policy, including the development of low-carbon and passive construction, over the next thirty years, greenhouse gas emissions can be reduced by up to $2 \mathrm{Gt}[5,6]$. Also optimistic is the fact that IEA reports show information on gradually decreasing oil consumption [1-5]. Despite that, American experts argue that the pace of development of technologies producing clean energy is still insufficient to visibly reduce the use of fossil fuels and offset the effects of the developing global economy [3-5]. Despite many promising forecasts, it should be advised that current energy policy often does not lead to shaping a secure energy future. Moreover, it often deviates from the common goals of sustainable development, which is why the spread of low carbon technologies is so important.

In the Global Risks Report from 2020 [7] published by the World Economic Forum (WEF), the researchers identified problems and threats that the contemporary world will have to overcome in the future. In their assessment, experts pointed out the threats directly related to the state of the environment and the climate. They concluded that such problems as e.g., climate change, degradation of ecosystems or problems related to water crisis are a real global threat and one should take into account the increased risk of their occurrence over the next 10 years. The results of the Global Risks Report surveys are presented in more detail in Figure 1.

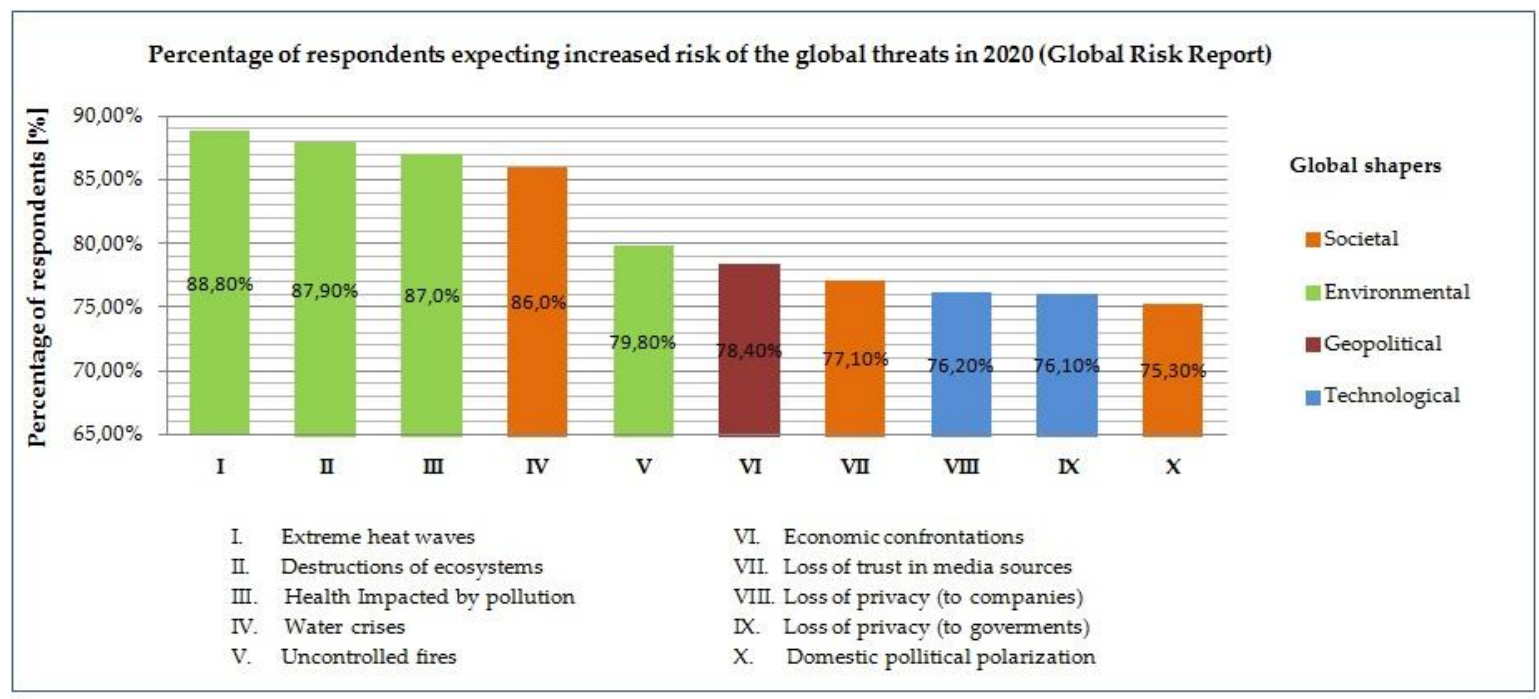

Figure 1. Risk forecast published in 2020 as part of the Global Risk Report issued by the World Economic Forum (WEF) [7].

The risk forecast included in this report [7] published by the World Economic Forum may indicate the increasing ecological awareness of society. For the first time in history, issues related to the state of the natural environment are among the most significant threats, both in the context of the negative degree of impact as well as the possibility of occurrence. However, climate changes are not a problem that has arisen over the past few years. Based on the report, it can be assessed that the presented forecast largely results from the increase in the ecological awareness of the society.

One of the actions carried out to reduce the environmental impact of the energy sector is the development of alternative energy sources [8-11]. According to the project overview Polish Energy Policy, by 2040 [12] the share of hard coal in electricity production is to be reduced to $60 \%$ in 2030. The priority in the project is also to increase the pressure to reduce greenhouse gas emissions to the atmosphere as well as to increase energy consumption efficiency and decarbonize the transport system [12]. The dissemination of low-carbon technologies in the building sector may play an important role in these activities, especially since buildings are estimated to consume around a quarter of the annual global energy supply [8-10,13]. 


\section{Possibilities of Heat Recovery from Sewage}

According to the data contained in literature [14-17] on heat energy deposited in gray water, it accounts for about $80-90 \%$ of primary energy in domestic hot water. It is estimated that every year in the United States alone, energy with a value of $350 \mathrm{TWh}$ is irrevocably expelled with gray water [18]. Heat captured in sewage can be recovered using heat exchangers installed directly under the shower drain or at the inlet to the sewage system. Waste heat recovery also takes place in the sewage network, as well as in the sewage treatment plants and is usually exploited using heat pumps. It is worth noting that according to research published in recent years, it was found that the efficiency of devices for heat recovery from sewage exceeds $50 \%$ [17-21], which may confirm the legitimacy of implementing such systems.

On the market, there are more and more types of heat exchangers. Those devices can be used independently, as a single heat exchanger, but also be implemented in more complex technical facilities. The heat exchangers intended to be installed directly under the shower drain include:

- heat exchanger-integrated showers,

- horizontal heat exchangers,

- vertical, counter-current heat exchangers, in which there are additionally distinguished:

a. spiral exchangers,

b. tube-in-tube heat exchangers.

Amongst the heat exchangers installed at the inlet to the sewage network, there are the following types of equipment:

- heat exchangers in the form of heat pipes,

- heat exchangers in the form of a tank with a coil, in which there are additionally distinguished:

a. heat from sewage retention heat exchangers,

b. heated water retention heat exchangers [18,21-23].

The effectiveness of heat exchangers in recovering energy from gray water in sewage systems depends on a number of functions [23-25], which is shown in Figure 2. Effectiveness of heat exchanging is calculated with the well-known Equation (1) [24,25].

$$
\varepsilon=\frac{\mathrm{T}_{2}-\mathrm{T}_{1}}{\mathrm{~T}_{3}-\mathrm{T}_{1}} \times 100
$$

where:

$\varepsilon$ is the heat exchanger efficiency, \%,

$\mathrm{T}_{1}$ is the cold tap water temperature, ${ }^{\circ} \mathrm{C}$,

$\mathrm{T}_{2}$ is the temperature of pre-heated water in the exchanger, ${ }^{\circ} \mathrm{C}$,

$\mathrm{T}_{3}$ is the gray water temperature at the inlet to the heat exchanger, ${ }^{\circ} \mathrm{C}$. 
FACTORS DETERMINING THE EFFICIENCY

OF WASTE HEAT RECEPTION FROM WASTEWATER

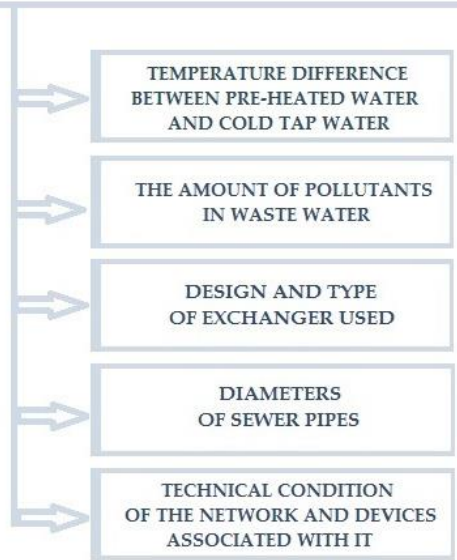

Figure 2. Factors determining the efficiency of waste heat recovery from wastewater [23-25].

In recent years, the state of knowledge in the field of heat recovery has changed significantly as well as the standards in the design and operation of sanitary installations. Water flow regulators are currently widely used to reduce the consumption of water. According to the available data, the flowrate of a shower head is between $7 \mathrm{dm}^{3} / \mathrm{min}$ and $12 \mathrm{dm}^{3} / \mathrm{min}$. As described by Mazhar et al. [18] the average water consumption in an average household per person during the day is about $150 \mathrm{dm}^{3}$. In addition, it is estimated that $41-91 \%$ of a household water consumption corresponds to gray water, with a potential for heat harnessing. A statistical resident of Great Britain uses about $70 \mathrm{dm}^{3}$ of water per day during a shower. For comparison, they use about $80 \mathrm{dm}^{3}$ of water while a bath is taken in a tub [18]. The average temperature of the domestic hot water supplied to the shower faucet is in the range from $40{ }^{\circ} \mathrm{C}$ to $50^{\circ} \mathrm{C}$. For cold water supplied to the installation from the water network, the average temperature is about $15^{\circ} \mathrm{C}[18,26,27]$. Depending on the location of the system and thusly the characteristic operational parameters, the heat recovery is carried out at a very different temperature [18,27], which is included in Table 1.

Table 1. Averaged values of heat exchange efficiency depending on selected characteristic parameters [18-28].

\begin{tabular}{|c|c|c|c|c|}
\hline $\begin{array}{l}\text { Location of Heat } \\
\text { Recovery System }\end{array}$ & Proposed Devices & $\begin{array}{c}\text { Temperature } \\
\text { Range }\end{array}$ & $\begin{array}{l}\text { Waste Water Flow } \\
\text { Rate }\end{array}$ & $\begin{array}{c}\text { Estimated Heat } \\
\text { Recovery } \\
\text { Efficiency }\end{array}$ \\
\hline $\begin{array}{l}\text { Heat exchangers } \\
\text { installed directly } \\
\text { under the shower } \\
\text { drain or at the inlet } \\
\text { to the sewage }\end{array}$ & $\begin{array}{c}\text { Vertical heat } \\
\text { exchangers, } \\
\text { horizontal heat } \\
\text { exchangers, heat } \\
\text { pumps }\end{array}$ & $40-50{ }^{\circ} \mathrm{C}$ [22-27] & $\begin{array}{c}2-20 \mathrm{dm}^{3} / \mathrm{min} \\
{[18,22-27]}\end{array}$ & $\begin{array}{c}<50 \% \text { of the first } \\
\text { energy content } \\
{[20,23,28]}\end{array}$ \\
\hline $\begin{array}{l}\text { Heat exchangers } \\
\text { installed on the } \\
\text { sewage network }\end{array}$ & $\begin{array}{c}\text { Vertical heat } \\
\text { exchangers, } \\
\text { horizontal heat } \\
\text { exchangers, heat } \\
\text { pumps }\end{array}$ & $\begin{array}{c}15-30{ }^{\circ} \mathrm{C} \\
{[18]}\end{array}$ & $\begin{array}{c}10000>\mathrm{dm}^{3} / \mathrm{min} \\
{[18]}\end{array}$ & $\begin{array}{c}40-50 \% \text { of the first } \\
\text { energy content } \\
{[18]}\end{array}$ \\
\hline $\begin{array}{l}\text { Heat exchangers } \\
\text { installed at the } \\
\text { outlet of sewage } \\
\text { treatment plant }\end{array}$ & Heat pumps & $\begin{array}{l}10-20{ }^{\circ} \mathrm{C} \\
{[18,19,26]}\end{array}$ & $\begin{array}{c}10000<\mathrm{dm}^{3} / \mathrm{min} \\
{[18,19,26]}\end{array}$ & $\begin{array}{c}10-30 \% \text { of the first } \\
\text { energy content } \\
{[21,26]}\end{array}$ \\
\hline
\end{tabular}


Heat recovery in sewage networks and sewage treatment plants seems to be justified due to the significant amount of flowing sewage. It should be noted, however, that sewage temperature is a very important factor affecting the efficiency of biochemical treatment processes, therefore heat exchangers should be installed only at the outlet of such installations $[29,30]$.

The differences in the values of heat from sewage produced can be significant and are strictly dependent on the value of the average water consumption per person. The amount of gray water produced per capita depending on the region of the world is presented in Figure 3. The lower and upper values of the average daily gray water generation can be associated with the geographical location in the regions. In some European communities, they result from the growing mentality of water saving. For African countries, differences in wastewater production depend mainly on the level of development and standard of living [16,18].

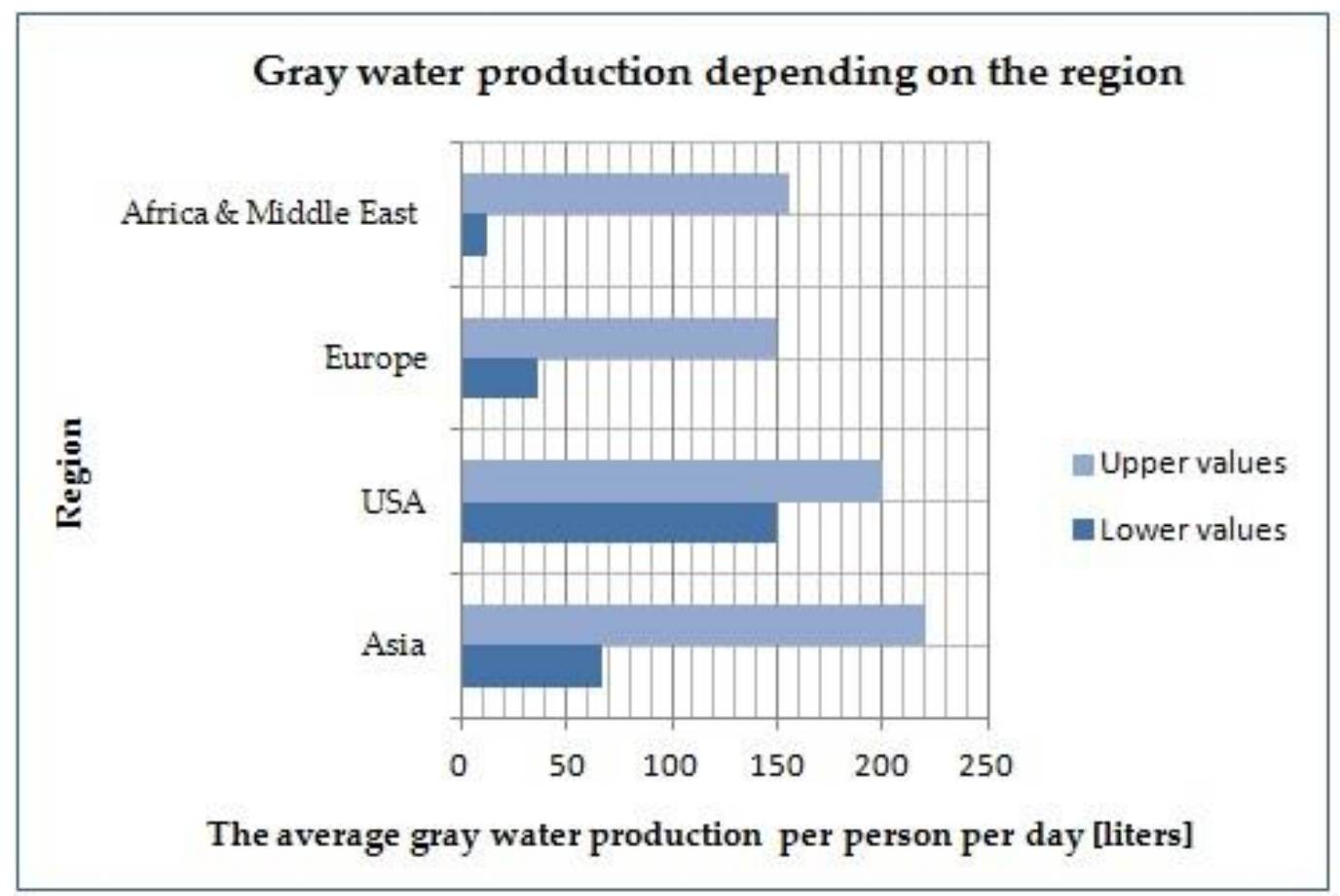

Figure 3. Gray water production per person depending on the region of the world [18].

As discussed by Mazhar et al. [18], usually the highest values of effluent gray water in households are recorded before and after local business hours. It was estimated that the largest amount of water is used during the shower. It should be noted that about $64 \%$ of the sewage produced in residential buildings is gray water, which has a high potential for heat recovery [31-34].

In the case of public buildings, the amount of gray water draining out is much higher $[29,35,36]$. For example, water consumption for bathing purposes in hospitals is about $327 \mathrm{dm}^{3}$ per one patient per day, which being a significantly high value influences the higher efficiency of receiving heat deposited in gray water [18,37-39].

The reviewed papers evaluated the impact of key and variable factors of the efficiency of heat energy recovery from gray water. Various types of installations and heat take-off units were tested, primarily assessing the economic and environmental benefits of their use. Research on heat recovery in sewer systems was most often carried out for vertical DWHR (Drain Water Heat Recovery) heat exchangers installed in residential buildings. In their works, the authors used various tools of analysis and data acquisition. 


\section{Selected Methods Used in the Analysis of Heat Recovery from Wastewater}

\subsection{Monte Carlo}

Monte Carlo analysis is an example of a probabilistic method that is based on multiple random sampling of process-specific quantities. In the research on heat recovery from gray water, basic parameters such as consumption of domestic hot water or temperature of flowing media are determined randomly, according to their observed distribution. This method is often used to simulate systems with multiple degrees of freedom and in cases of uncertainty regarding the estimation of the input parameters [40,41].

\subsection{Life Cycle Cost (LCC)}

Life Cycle Cost (LCC) is an economic analysis tool used to determine the profitability of the solution being considered. This methodology makes it possible to compare different investment options in financial terms. LCC is used to determine the so-called live costs, which include initial investment outlays, as well as operating costs. It can be used in various areas of the economy, including in the energy, manufacturing, and construction industries, and used as a tool in decision making and management $[22,23]$.

\subsection{PESTEL}

PESTEL (Political, Economic, Social, Technological, Environmental, Legal) macro-environment factors analysis is a tool used to support strategic decision making from the operating point of view. The analysis allows to create a plan for further research and facilitates the identification and classification of external factors that affect the analyzed model. This tool is used in many industries, including broadly understood environmental engineering and the energy sector [42].

\subsection{Computational Fluid Dynamics (CFD)}

Computational Fluid Dynamics (CFD) is a tool that can significantly reduce design time and the costs related to the implementation of a given solution. This computer simulation allows to examine every aspect of the operation of a given product with very high accuracy, from its physical properties to issues related to control. It also gives the opportunity to optimize existing models and allows for efficient analysis of the impact of design changes on their characteristics [43-45]. There are many commercial computer simulation programs on the market that allow us to obtain solutions for numerical equations describing a given model using methods such as:

- $\quad$ Finite Element Method (FEM).

- $\quad$ Finite Volume Method (FVM).

- Finite Difference Method (FDM).

- Boundary Element Method (BEM) $[45,46]$.

\subsection{TRNSYS}

TRNSYS software is a transient simulation program commonly used in energy management research. With the use of TRNSYS, it is possible to conduct non-stationary simulations of complex energy conversion systems interacting with a building. Simulations conducted using TRNSYS tools are characterized by a high degree of mapping reality [47]. In the literature, information can be found that this degree may be greater than $90 \%$ [47-50]. The use of this software in the design stage can significantly help to indicate and eliminate many problems such as low performance of the designed system or potential hazards associated with its operation, e.g., overheating of components [50,51]. 


\subsection{Pinch Analysys}

Pinch analysis is a method used to optimize thermal systems in process engineering involving the search for systems with high heat recovery potential and low thermal losses. It is associated with the analysis of various operating conditions of these thermal systems, as well as their modification. This method is currently not widely used in the design of energy-efficient buildings due to the difficulties in identifying potential heat sources, especially in the case of waste heat and renewable energy. Pinch analysis in waste energy recovery research was first used by Su et al. The test was carried out for the building, taking into account previously assumed thermal requirements such as thermal comfort of the residents and consumption of domestic hot water [52].

\section{Results and Discussion}

The efficiency of waste heat recovery systems primarily depends on the temperature of sewage and water, which was confirmed by an experimental analysis conducted by, among others, Manouchehri et al. [35]. It has been shown that changes in the efficiency of waste heat recovery from gray water depend mainly on the temperature of flowing media and occur irrespective of the physical parameters characterizing the device as well as operational parameters. Those conclusions were based on the research of four DWHR systems of various dimensions. Tests were carried out for the set temperature at the exchanger inlet of $25^{\circ} \mathrm{C}, 30^{\circ} \mathrm{C}, 35^{\circ} \mathrm{C}, 40^{\circ} \mathrm{C}$, and $45^{\circ} \mathrm{C}$ and for tap water temperatures of $5^{\circ} \mathrm{C}, 10^{\circ} \mathrm{C}, 15^{\circ} \mathrm{C}, 20^{\circ} \mathrm{C}$, and $30^{\circ} \mathrm{C}$, respectively. The experiment confirmed the close correlation of heat removal efficiency with the temperature of the flowing media. It was determined that an increase in any of these temperatures would lead to an increase in efficiency, even if the temperature difference between the inlets was constant. It was found that efficiency changes occur irrespective of diameter, length, or flow rate. Analyzing the results of the work of Zaloum et al. [53] conducted for horizontal DWHR units, different conclusions can be noted. The results of the experimental analysis for real models allow us to state that the most significant parameter affecting the efficiency of the receipt of deposited heat is the impact of media flow speed.

Water usage involving the shower is one of the key factors in assessing the rationality of using a unit for heat recovery. Spriet et al. [54] used the measurement data from over 100 residential buildings. The purpose of their analysis was to determine the daily and monthly gray sewage production profiles. They were used to test the operation of the heat recovery system, but they can also be included in the assessment of the operation of other systems, e.g., solar installations. The authors of the work carried out an analysis of the operation of DWHR systems on a basis of a monitoring campaign in three houses, measuring the temperature and flow of sewage at intervals of $5 \mathrm{~min}$, for a period of one year. Based on the probabilistic method of Monte Carlo mathematical modeling, they determined the potential for reducing greenhouse gas emissions associated with heating in range of 7.6-22\%. In the case under study, however, this increased heating costs by $120-130 \%$. It was found that at current heating prices, the implementation of the DWHR system is not financially attractive compared to traditional hot water preparation systems due to significant capital expenditures.

Horizontal heat exchangers were also evaluated for their purposefulness of use. The conducted analyses were directed, among others, at developing new solutions assuming the elimination of existing structural defects [24,40]. Pochwat et al. [24] studied the shape of baffles in prototype heat exchangers, as well as the impact of the tilt of the unit body on the heat collection efficiency. Studies have shown that equipping units with properly shaped baffles or introducing water flow limiters in the system can significantly increase the efficiency of thermal energy reception. The analysis showed that the use of this solution to limit the flow is particularly profitable in the case of buildings with high water consumption and high user turnover.

A similar experimental analysis aimed at assessing the structural solution in terms of introducing improvements was carried out by Bartkowiak et al. [40]. The prototype flat heat exchanger was tested for various media flows and their temperatures. The analysis shows that the use of the DWHR unit can save an average of USD 74 per year per household with natural gas water heaters and USD 160 per 
year for homes with electric water heaters. The paper also describes the environmental benefits that can be achieved through the use of DWHR systems, which result directly from the reduction of energy consumption. The Monte Carlo analysis used by the researchers showed that the system can minimize $\mathrm{CO}_{2}$ emissions to the atmosphere by $0.3 \mathrm{t}$ and $1.5 \mathrm{t}$ per one residential building during the year. The values described correspond in turn to the integrated systems with gas and electric heaters. In their work, Bartkowiak et al. [40] collected the results obtained for the needs of research and then introduced them into the software, which allows potential users to estimate the savings resulting from the use of DWHR units after entering specific data on the location of the system and bathing habits.

The lifetime of the heat exchangers units, so-called live costs and the efficiency of heat collection from gray water are the examples of the parameters related to the profitability of using DWHR systems. Financial analyses carried out for vertical DWHR units and for different flow rates and different temperatures of flowing media indicate that the possibility of recovering available energy is in the range of about $34-60 \%$ [55-57].

The economic justification for using heat exchangers in residential buildings depends not only on the operational parameters of the installation, but also on the amount of gray water produced. Profitability of waste heat recovery installations from gray water and domestic hot water preparation is also associated with the type of water heater [57]. According to the research by Kordana et al. [57], the financial benefits are most satisfactory when using an electric heater, and the payback time is within the lifetime of the DWHR units.

Another method which can be facilitated in the decision-making process when selecting or modernizing heat recovery installations from sewage in shower systems in single-family buildings can be presented by Słyś et al. [22] computational model. A simulation test was carried out, on the basis of which the most financially advantageous heat recovery installation variant was determined using the water flow limiter proposed by the authors. It was found that the use of the presented solution will be particularly profitable for buildings with significant water consumption and high user turnover.

The next example tool presented in the analyzed works that can facilitate the decision-making process when selecting or modernizing heat recovery installations deposited in gray water is the example of the Ramadan et al. [27] model, which in their work described a calculation procedure that can be used to pre-assess the suitability of the chosen solution or to optimize it. The analysis confirmed that some system configurations may show better efficiency in recovering heat from gray water, and thus their use is much more rational. As noted by Spriet el al. [58] sewage treatment plants can sometimes produce significant excess heat, which allows the integration of heat recovery systems deposited in gray water with the energy system not only within the facility, but also at the stage of sewage transport. The recovered heat is mainly used for the needs of preparing domestic hot water, as well as for the purposes of reducing electricity consumption in technological gray water treatment processes. The recovery of deposited heat is most often carried out using heat pumps, for which warm wastewater is the lower heat source. When electricity is generated by the heat pump systems used from renewable energy, there are low or zero emissions, which is of great importance for the development of a secure energy future. In their work, Spriet el al. [58] focused on analyzing the success of energy reception by consumers near the gray water treatment plant, i.e., $2 \mathrm{~km}$ from the facility. The paper describes a three-stage analysis, which included the energy assessment of a sewage treatment plant, a spatio-temporal analysis, and an analysis of supply and demand. The proposed three-step methodology was supposed to allow for the consideration of both the proximity of potential consumers in the research and possible time gaps between supply and demand for energy. Research was carried out for a case study in Ireland to help identify potential related risks with dimensioning of networks and systems for generating and receiving energy. In their work, the authors state that the use of waste heat can have a valuable contribution to energy demand for urban systems, as it was determined that the analyzed system can provide about $58-93 \%$ of its total consumption. However, attention should be paid to the time adjustment of energy supply and demand, as the available amount of heat was sometimes not sufficient to meet energy expectation. 
Research on heat recovery from gray water carried out by Morales-Ruiz et al. [59] instead focused on a detailed analysis of the PCM (Phase Change Materials) board thermal energy storage module, which can interact with the installation of heat recovery from gray wastewater. The global numerical algorithm was used in the research. Numerical and experimental tests were performed to analyze the performance of the designed unit. Experimental data allowed verification of the correctness of the numerical results obtained. It was estimated that there was a discrepancy between the numerical values and experimental data for the heat exchange process, which was estimated at about $7.2 \%$. The study specifies that the designed PCM heat storage unit can hold about $75 \%$ of the energy obtained in the process of its recovery.

In their research, scientists also broached the issue of the efficiency of heat recovery units integrated with solar systems (SDHW) [60-65]. In the paper, Tanha et al. [51] presented a simulation of SDHW hybrid systems operation in a typical household in Ontario (Canada). The first system included a flat solar collector and a DWHR unit supported by a gas boiler, while the second solution was a tubular solar collector and a DWHR unit supported by an electric tank. In each system, the heat transfer medium in the collector loop was a mixture of water and propylene glycol (60:40 ratio). The simulation was carried out using TRNSYS software, and the obtained results prove the legitimacy of using such installation. The hybrid solar systems with heat recovery allowed us to minimize the demand for electricity. During the year, SDWH units based on flat collectors generated $2038 \mathrm{kWh}$ of thermal energy, while in the case of tubular collectors, the amount of generated energy is lower and amounts to $1383 \mathrm{kWh}$. Tanha et al. [50] continuing research in the subject of SDHW systems, they carried out another simulation for the solar systems described earlier. In this case, TRNSYS simulation was also used and the models were checked against the experimental data. It was estimated that the DWHR unit integrated with a flat solar collector saved $1831 \mathrm{kWh}$ of energy per year, while an installation with a tubular collector could reduce its demand by $1771 \mathrm{kWh}$. Tanha et al. by extrapolating data obtained during experimental studies proved that SHDW systems can recover $789 \mathrm{kWh}$ of thermal energy annually. Based on the analyses carried out, they assessed that DWHR units in combination with solar installations can achieve heat recovery efficiency at the level of 50\% [51].

Paduchowska et al. [66] conducted an analysis of the energy savings needed to prepare domestic hot water resulting from the use of heat collection units in multi-story buildings, i.e., for two dorms in Wroclaw (Poland). The buildings have 10 residential floors each and in total there are 120 residential modules with bathrooms. A DHW circulation system was only provided in one of those buildings. The tests determined that the outlet temperature from the shower is to be equal to $45^{\circ} \mathrm{C}$. After being installed, it was noticed that the consumption of hot water in dorms was higher than the level set by Polish standards. It was found that the implementation of waste heat recovery systems can bring significant financial and environmental benefits. The technology can save from 110.14 to $121.15 \mathrm{GJ}$ in a building without continuous DHW circulation in the installation and from 164.28 to 205.93 GJ for a building with circulation.

Noteworthy studies were presented by Reddick et al. [47], who used TRYNSYS modeling and innovative analysis of approaching points. The subject of the study was a three-story building inhabited by 17 people, and the purpose of the research was to determine the possibilities of reducing electricity consumption depending on the adopted scenarios of solutions for systems and heat sources. For the purposes of the analysis, it was assumed that solar collectors operate in the building, while underfloor heating and air conditioning were also used. For the purposes of the analysis, it was also assumed that every day 17 inhabitants consume $380 \mathrm{~L}$ per person, of which $110 \mathrm{~L}$ were to be hot water needed for utility purposes. It is worth noting that the values of water consumed are much higher compared to data published in the European reports or presented in analyses [67-69]. This situation results from much lower fees related to water supply and electricity in relation to other regions of the world. In comparison with a building equipped only with solar collectors, electricity consumption could be reduced by $31 \%$, additionally introducing sewage separation and heat recovery using a plate heat exchanger. In addition, comparing a building equipped only with solar collectors, electricity 
consumption can be reduced by $42 \%$ by running a heat pump, and at the same time giving up the use of sewage separation. On the other hand, the combination of a sewage separation system and a heat pump can reduce electricity consumption by $53 \%$. If the reference point was a building for which no solar collectors were used, the total benefit from the implementation of the sewage system with the distribution of sewage, heat pumps, and additional solar panels can achieve a reduction of electricity consumption by as much as $64 \%$. Reddick et al. [47] additionally conducted two economic analyses for the building assuming that no solar collectors were used, and for the second option, solar energy is foreseen. It was estimated that payback periods ranged from 1 to 10 years; however, the results were strongly influenced by the low cost of electricity in Quebec and as noted by Reddick et al. [47], the relatively high cost of buying a heat pump. It is worth noting that the analysis did not include government financial programs.

\section{Conclusions}

Examples of implementation of gray water heat recovery units presented in the literature indicate the desirability of using them as a valuable source of energy not only in multi-story buildings, where significant water consumption is observed, but also in single-family buildings. Recent research confirms that the cooperation of heat exchangers with a sewage system and system of preparation domestic hot water is economically and environmentally reasoned. This is due to the reduction in energy demand for hot water, and it reduces the costs of maintaining the building and greenhouse gas emissions. In assessing the legitimacy of heat recovery from gray water, it should be noted that gray water is independent of atmospheric conditions compared to other alternative energy sources. This enables comfort in using the system.

The interest of scientists around the subject of heat energy recovery, and above all the results of the conducted analyzes testify to the legitimacy of using heat recovery technology from gray water in sewage systems. The published results of experimental research as well as the presented calculation methods and procedures can significantly facilitate the assessment and analysis of the legitimacy of using a given heat recovery unit for specific installation parameters. The use of energy from sewage is particularly justified in passive buildings, whose design concept allows for reducing the need for heating and cooling of space, but does not take into account the minimization of energy consumption for the preparation of domestic hot water, so it is estimated that it can constitute up to $50 \%$ of the total energy demand.

Based on the review of the research, it can be concluded that the issue of energy recovery from gray water has not been sufficiently developed. Most publications are carried out on the subject of heat recovery from gray water focused on research conducted for residential buildings. The conditions for heat recovery for larger scale systems, e.g., urban agglomeration as well as in industry, have not been sufficiently discussed. Energy recovery potential studies for cities as well as in industry, have not been conducted looking for the influence of city's number of inhabitants, households, or public buildings. It seems reasonable to conduct research on the advisability of combining gray water streams from different buildings to provide a greater sewage flow, which may involve potentially high amounts of heat recovery, which in turn could significantly improve the profitability of the installation. In the case of heat recovery in industrial sewage installations, it would be necessary to carry out research on sewage with different temperatures and different degrees of pollution, coming from specific industries.

Research results published in recent years have often been focused on improving already available technologies for thermal energy collection, not only in the construction industry and municipal engineering, but also in various areas of the economy. An example may be research carried out in the field of testing engine systems in the aviation and automotive industry [70,71].

Popularization of heat removal technology from gray water is justified, especially because of the need to promote the energy from renewable sources, which is no longer just a "good habit", but is legally regulated, including in Directive (EU) 2018/2001 of the European Parliament and of the Council of 11 December 2018 on the promotion of the use of energy from renewable sources [72]. 
Author Contributions: Conceptualization B.P., D.S. and S.K.-O., K.P.; methodology B.P.; formal analysis D.S.; writing—original draft preparation, B.P., D.S.; writing—review B.P. and D.S.; editing, B.P.; supervision: D.S. and S.K.-O., K.P. All authors have read and agreed to the published version of the manuscript.

Funding: This research received no external funding.

Conflicts of Interest: The authors declare no conflict of interest. The funders had no role in the design of the study; in the collection, analyses, or interpretation of data; in the writing of the manuscript, or in the decision to publish the results.

\section{References}

1. EIA. International Energy Outlook 2019. U.S. Energy Information Administration. Available online: https://www.eia.gov/outlooks/ieo/pdf/ieo2019.pdf (accessed on 1 April 2020).

2. EIA. International Energy Outlook 2018. U.S. Energy Information Administration. Available online: https://www.eia.gov/pressroom/presentations/capuano_07242018.pdf (accessed on 5 December 2019).

3. International Energy Agency. World Energy Outlook 2019. Flagship Report-November 2019. Available online: https://www.iea.org/topics/world-energy-outlook (accessed on 3 April 2020).

4. EIA. International Energy Renewables 2019. U.S. Energy Information Administration. Available online: https://www.iea.org/reports/renewables-2019 (accessed on 2 April 2020).

5. International Energy Agency. Tracking Clean Energy Progress 2016. In Energy Technology Perspectives 2016; International Energy Agency: Paris, France, 2016.

6. International Energy Agency. Technology Roadmap: Energy Efficient Buildings, Heating and Cooling Equipment; International Energy Agency: Paris, France, 2011.

7. WEF. Global Risks Report 2020. Available online: https://www.weforum.org/reports/the-global-risks-report-2020 (accessed on 3 April 2019).

8. Stec, A.; Kordana, S. Analysis of profitability of rainwater harvesting, gray water recycling and drain water heat recovery systems. Resour. Conserv. Recycl. 2015, 105, 84-94. [CrossRef]

9. Wanjiru, E.; Xia, X. Optimal energy-water management in urban residential buildings through grey water recycling. Sustain. Cities Soc. 2017, 32, 654-668. [CrossRef]

10. Niewitecka, K. Possibilities of heat energy recovery from greywater systems. E3S Web Conf. 2018, 30, 3003. [CrossRef]

11. Li, X.; Gul, M.; Sharmin, T.; Nikolaidis, I.; Al-Hussein, M. A framework to monitor the integrated multi-source space heating systems to improve the design of the control system. Energy Build. 2014, 72, 398-410. [CrossRef]

12. Energy Policy of Poland until 2040 (EPP 2040). Available online: http://seo.org.pl/en/zaktualizowany-projektpolityki-energetycznej-polski-do-2040-r (accessed on 2 April 2019).

13. Merkel, E.; McKenna, R.; Fehrenbach, D.; Fichtner, W. A model-based assessment of climate and energy targets for the German residential heat system. J. Clean. Prod. 2017, 142, 3151-3173. [CrossRef]

14. Meggers, F.; Leibundgut, H. The potential of wastewater heat and exergy: Decentralized high-temperature recovery with a heat pump. Energy Build. 2011, 43, 879-886. [CrossRef]

15. Eslami-Nejad, P.; Bernier, M. Impact of Grey Water heat recovery on the electrical demand of domestic hot water heaters. In Proceedings of the Eleventh International IBPSA Conference, Glasgow, UK, 27-30 July 2009; pp. 681-687.

16. Boyjoo, Y.; Pareek, V.; Ang, M. A review of greywater characteristics and treatment processes. Water Sci. Technol. 2013, 67, 1403-1424. [CrossRef] [PubMed]

17. Hage, H.; Ramadan, M.; Jaber, H.; Khaled, M.; Olabi, A.G. A short review on the techniques of waste heat recovery from domestic applications. Energy Sources 2019, 7, 1-16. [CrossRef]

18. Mazhar, A.; Liu, S.; Shukla, A. A key review of non-industrial greywater heat harnessing. Energies 2018, 11, 386. [CrossRef]

19. Kretschmer, F.; Simperler, L.; Ertl, T. Analysing wastewater temperature development in a sewer system as a basis for the evaluation of wastewater heat recovery potentials. Energy Build. 2016, 128, 639-648. [CrossRef]

20. Juan, Y.K.; Chen, Y.; Lin, J.M. Greywater reuse system design and economic analysis for residential buildings in Taiwan. Water 2016, 8, 546. [CrossRef] 
21. Bertrand, A.; Mastrucci, A.; Schüler, N.; Aggoune, R.; Wang, L. Characterisation of domestic hot water end-uses for integrated urban thermal energy assessment and optimisation. Appl. Energy 2017, 186, 152-166. [CrossRef]

22. Słyś, D.; Kordana, S. Financial analysis of the implementation of a Drain Water Heat Recovery unit in residential housing. Energy Build. 2014, 71, 1-11. [CrossRef]

23. Stec, A.; Kordana, S.; Słyś, D. Analysing the financial efficiency of use of water and energy saving systems in single-family homes. J. Clean. Prod. 2017, 151, 193-205. [CrossRef]

24. Pochwat, K.; Kordana, S.; Starzec, M.; Słyś, D. Comparison of two-prototype near-horizontal Drain Water Heat Recovery units on the basis of effectiveness. Energy 2019, 173, 1196-1207. [CrossRef]

25. Collins, M.R.; Decker, G.E.; Murray, J. Characteristic effectiveness curves for falling-film drain water heat recovery systems. HVAC R Res. 2013, 19, 649-662.

26. Gabor, T.; Dan, V.; Tiuc, A.E.; Sur, I.M.; Badila, I.N. Modelling and simulation of heat transfer processes for heat exchangers used in wastewater treatment. Environ. Eng. Manag. J. 2016, 15, 1027-1033. [CrossRef]

27. Ramadan, M.; Al Shaer, A.; Haddad, A.; Khaled, M. An experimental study on recovering heat from domestic drain water. AIP Conf. Proc. 2016, 1758, 030011. [CrossRef]

28. Taemthong, W. Grey water recycling for reuse in toilet flushing: A case study in Thailand. Int. J. Environ. Sci. Dev. 2017, 8, 421-424. [CrossRef]

29. Spriet, J.; McNabola, A. Decentralized drain water heat recovery from commercial kitchens in the hospitality sector. Energy Build. 2019, 194, 247-259. [CrossRef]

30. Ziembowicz, S.; Kida, M.; Koszelnik, P. The impact of selected parameters on the formation of hydrogen peroxide by sonochemical process. Separ. Purif. Technol. 2018, 2, 188. [CrossRef]

31. Wong, L.; Mui, K.W.; Guan, Y. Shower water heat recovery in high-rise residential buildings of Hong Kong. Appl. Energy 2010, 87, 703-709. [CrossRef]

32. Kordana, S. An assessment of the potential for shower water heat recovery. E3S Web Conf. 2018, 45, 00034. [CrossRef]

33. Alnahhal, S.; Spremberg, E. Contribution to Exemplary In-House Wastewater Heat Recovery in Berlin, Germany. Procedia CIRP 2016, 40, 35-40. [CrossRef]

34. Manouchehri, R.; Collins, M.R. An experimental analysis of the impact of temperature on falling film drain water heat recovery system effectiveness. Energy Build. 2016, 130, 1-7. [CrossRef]

35. Manouchehri, R.; Collins, M.R. An experimental analysis of the impact of unequal flow on falling film drain water heat recovery system performance. Energy Build. 2018, 165, 150-159. [CrossRef]

36. Dudkiewicz, E.; Ludwińska, A.; Rajski, K. Implementation of greywater heat recovery system in hospitals. E3S Web Conf. 2019, 116, 00018. [CrossRef]

37. McNabola, A.; Shields, K. Efficient drain water heat recovery in horizontal domestic shower drains. Energy Build. 2013, 59, 44-49. [CrossRef]

38. Wallin, J.; Claesson, J. Investigating the efficiency of a vertical inline drain water heat recovery heat exchanger in a system boosted with a heat pump. Energy Build. 2014, 80, 7-16. [CrossRef]

39. Prabu, S.S.; Asokan, M.A. A study of waste heat recovery from diesel engine exhaust using phase change material. Int. J. Chem. Tech. Res. 2015, 8,711-717.

40. Bartkowiak, S.; Fisk, R.; Funk, A.; Hair, J.; Skerlos, S.J. Residential drain water heat recovery systems: Modeling, analysis, and implementation. J. Green Build. 2010, 5, 85-94. [CrossRef]

41. Fishman, G.S. Monte Carlo: Concepts, Algorithms and Applications; Springer: New York, NY, USA, 1996; pp. 66-70.

42. Kordana, S.; Pochwat, K.; Słyś, D.; Starzec, M. Opportunities and threats of implementing drain water heat recovery units in Poland. Resources 2019, 8, 88. [CrossRef]

43. Winkler, D.; Zischg, J.; Rauch, W. Virtual reality in urban water management: Communicating urban flooding with particle-based CFD simulations. Water Sci. Technol. 2017, 77, 518-524. [CrossRef] [PubMed]

44. Dabiri, E.; Noori, M.; Zahmatkesh, S. Modeling and CFD simulation of volatile organic compounds removal from wastewater by membrane gas stripping using an electro-spun nanofiber membrane. J. Water Process. Eng. 2018, 30. [CrossRef]

45. Echi, S.; Bouabid, A. CFD simulation and optimization of industrial boiler. Energy 2019, 169, $105-114$. [CrossRef] 
46. Akbarzadeh, P.; Abbasnejad, A.; Movahed, F.; Zolfaghari, S. A new approach to numerical investigation of GFX and power-pipe drain water heat recovery (DWHR) systems in buildings. Heat Transf. Res. 2018, 49, 1339-1352. [CrossRef]

47. Reddick, C.; Sorin, M.; Bonhivers, J.C.; Laperle, D. Waste heat and renewable energy integration in buildings. Energy Build. 2020, 211, 1-15. [CrossRef]

48. Kalogirou, S.; Papamarcou, C. Modelling of a Thermosyphon Solar Water Heating System and Simple Model Validation. Renew. Energy 2000, 21, 471-493. [CrossRef]

49. Duffie, J.A.; William, A.B. Solar Engineering of Thermal Processes; John Wiley \& Sons, Inc.: New York, NY, USA, 2013; pp. 505-539.

50. Tanha, K.; Fung, A.S.; Kumar, R. Simulation and experimental investigation of two hybrid solar domestic water heaters with drain water heat recovery. Int. J. Energy Res. 2015, 39, 1879-1889. [CrossRef]

51. Tanha, K.; Fung, A.S.; Kumar, R. Performance of two domestic solar water heaters with drain heat recovery units: Simulation and experimental investigation. Appl. Therm. Eng. 2015, 90, 444-459. [CrossRef]

52. Su, W.; Ye, Y.; Zhang, C.; Balezentis, T.; Streimikiene, D. Sustainable energy development in the major power-generating countries of the European Union: The Pinch Analysis. J. Clean. Prod. 2020, 256. [CrossRef]

53. Zaloum, C.; Lafrance, M.; Gusdorf, J. Drain Water Heat Recovery Characterization and Modeling-Final Draft, Sustainable Buildings and Communities; Natural Resources Canada: Ottawa, ON, Canada, 2007; pp. 1-44.

54. Spriet, J.; McNabola, A. Decentralized Drain Water Heat Recovery: Interaction between Wastewater and Heating Flows on a Single Residence Scale. Proceedings 2018, 2, 583. [CrossRef]

55. Torras, S.; Oliet, C.; Rigola, J.; Oliva, A. Drain water heat recovery storage-type unit for residential housing. Appl. Therm. Eng. 2016, 103, 670-683. [CrossRef]

56. Bertrand, A.; Aggoune, R.; Wang, L. In-building waste water heat recovery: An urban-scale method for the characterisation of water streams and the assessment of energy savings and costs. Appl. Energy 2017, 192, 110-125. [CrossRef]

57. Kordana, S.; Słyś, D.; Dziopak, J. Rationalization of water and energy consumption in shower systems of single-family dwelling houses. J. Clean. Prod. 2014, 82, 58-69. [CrossRef]

58. Spriet, J.; McNabola, A.; Neugebauer, G.; Stoeglehner, G.; Ertl, T.; Kretschmer, F. Spatial and temporal considerations in the performance of wastewater heat recovery systems. J. Clean. Prod. 2020, 247. [CrossRef]

59. Morales-Ruiz, S.; Rigola, J.; Oliet, C.; Oliva, A. Analysis and design of a drain water heat recovery storage unit based on PCM plates. Appl. Energy 2016, 179, 1006-1019. [CrossRef]

60. Hasan, H.A.; Sopian, K.; Fudholi, A. Photovoltaic thermal solar water collector designed with a jet collision system. Energy 2018, 161, 412-424. [CrossRef]

61. Tewari, K.; Dev, R. Exergy, environmental and economic analysis of modified domestic solar water heater with glass-to-glass PV module. Energy 2019, 170, 1130-1150. [CrossRef]

62. Sami, S.; Semmar, D.; Hamid, A.; Mecheri, R.; Yaiche, M. Viability of integrating solar water heating systems into high energy performance housing in Algeria. Energy 2018, 149, 354-363. [CrossRef]

63. Launay, S.; Kadoch, B.; Le Métayer, O.; Parrado, C. Analysis strategy for multi-criteria optimization: Application to inter-seasonal solar heat storage for residential building needs. Energy 2019, 171, 419-434. [CrossRef]

64. Yang, W.; Zhang, H.; Liang, X. Experimental performance evaluation and parametric study of a solar-ground source heat pump system operated in heating modes. Energy 2018, 149, 173-189. [CrossRef]

65. Fertahi, S.E.-D.; Bouhal, T.; Gargab, F.; Jamil, A.; Kousksou, T.; Benbassou, A. Design and thermal performance optimization of a forced collective solar hot water production system in Morocco for energy saving in residential buildings. Sol. Energy 2018, 160, 260-274. [CrossRef]

66. Paduchowska, J.; Żabnieńska-Góra, A.; Polarczyk, I. Energy-saving analysis of grey water heat recovery systems for student dormitory. E3S Web Conf. 2019, 116, 00056. [CrossRef]

67. Marinoski, A.K.; Rupp, R.; Ghisi, E. Environmental benefit analysis of strategies for potable water savings in residential buildings. J. Environ. Manag. 2018, 206, 28-39. [CrossRef] [PubMed]

68. Leidl, C.M.; Lubitz, W.D. Comparing domestic water heating technologies. Technol. Soc. 2009, 31, $244-256$. [CrossRef]

69. Manouchehri, R.; Banister, C.J.; Collins, M.R. Impact of small tilt angles on the performance of falling film drain water heat recovery systems. Energy Build. 2015, 102, 181-186. [CrossRef] 
70. Saridakis, S.; Papanikolaou, N.; Voglitsis, D.; Koutroulis, E.; Tatakis, E.; Christidis, G.; Karatzaferis, I. Reliability analysis for a waste heat recovery power electronic interface applied at all-electric aircrafts. In Proceedings of the 2015 International Conference on Electrical Systems for Aircraft, Railway, Ship Propulsion and Road Vehicles (ESARS), Aachen, Germany, 3-5 March 2015. [CrossRef]

71. Shon, J.; Kim, H.; Lee, K. Improved heat storage rate for an automobile coolant waste heat recovery system using phase-change material in a fin-tube heat exchanger. Appl. Energy 2014, 113, 680-689. [CrossRef]

72. Directive (EU) 2018/2001 of the European Parliament and of the Council of 11 December 2018 on the Promotion of the Use of Energy from Renewable Sources. Available online: https:/eur-lex.europa.eu/legalcontent/EN/TXT/PDF/?uri=CELEX:32018L2001\&from=EN (accessed on 5 December 2019).

(C) 2020 by the authors. Licensee MDPI, Basel, Switzerland. This article is an open access article distributed under the terms and conditions of the Creative Commons Attribution (CC BY) license (http://creativecommons.org/licenses/by/4.0/). 